\title{
Podsumowanie i wnioski
}

Rozwijające się gwałtownie od ponad trzech dekad Chiny aspirują do miana mocarstwa globalnego. Szybki wzrost gospodarczy, modernizacja sił zbrojnych czy też aktywność dyplomatyczna stanowią o globalnym potencjale Państwa Środka. Coraz częściej też Chiny są postrzegane przez pryzmat wyłaniającego się układu dwubiegunowego, zwłaszcza w Azji Wschodniej, a ich działania ukierunkowane są na budowanie silnego zaplecza politycznego. Analiza postępowania Pekinu w odniesieniu do globalnych graczy międzynarodowych wskazuje, że wykorzystywane są takie środki, które kształtują pożądane postawy innych podmiotów, takie, które są odpowiedzią na działania tychże, oraz takie, które w głównej mierze są reakcją na politykę Stanów Zjednoczonych na omawianych obszarach. Wykorzystując rosnący potencjał gospodarczy, Chińska Republika Ludowa próbuje włączyć się w budowę nowego ładu międzynarodowego. Jednak takie ambicje są równoległe do tych wszystkich działań, które są ukierunkowane na podtrzymanie pokojowych relacji i unikanie szerszego konfliktu ze Stanami Zjednoczonymi. Chiny wyraźnie zdefiniowały swój interes, rozumiany jako „wielkie odrodzenie narodu chińskiego" i poczyniły pragmatyczne starania dotyczące adekwatnego do stawianych celów wykorzystania narzędzi polityki zagranicznej. Z punktu widzenia tak zdefiniowanego interesu narodowego nadal najważniejszym regionem w polityce chińskiej jest Azja Wschodnia i Południowo-Wschodnia, a celem strategicznym osiągnięcie integracji terytorialnej i stworzenie stabilnych warunków do dhugofalowego wzrostu gospodarczego.

W odniesieniu do realiów realizowania chińskiego celu w polityce zagranicznej podstawowym wyzwaniem stała się jednak konieczność balansowania wpływów amerykańskich w regionie. Po przejęciu władzy przez Hu Jintao w 2002 r. dyplomacja chińska starała się ograniczać amerykańską aktywność w Azji Wschodniej. W wyniku kryzysu ekonomicznego dominacja Waszyngtonu została ograniczona do wymiaru wojskowego i przewagi technologicznej, a kryzys dodatkowo spowodował spadek znaczenia dolara amerykańskiego na międzynarodowych rynkach. Z punktu widzenia Chin i stosowanych narzędzi w polityce wobec USA sytuacja ta przedstawiała się korzystnie.

Autorzy analizy sporządzili zestawienie tabelaryczne, aby porównać wagę relacji Chińskiej Republiki Ludowej z państwami i regionami będącymi przedmiotem analizy. Dodatkowo tabela posłużyła do porównania zastosowanych 
przez chińską politykę zagraniczną środków i metod do realizacji stawianych celów. Ogólny wniosek, jaki można sformułować po przeprowadzeniu analizy, sprowadza się do wyeksponowania szczególnej roli Stanów Zjednoczonych jako punktu odniesienia chińskiej polityki zagranicznej i strategii wobec innych graczy międzynarodowych. Autorzy zwracają również uwagę na fakt, że nadal najważniejszym adresatem polityki zagranicznej Chin pozostają państwa regionu - ASEAN i Japonia.

Tabela 9.1.

Narzędzia stosowane przez ChRL wobec poszczególnych aktorów
stosunków międzynarodowych

\begin{tabular}{|c|c|c|c|c|c|}
\hline & & & & & \\
\hline & & \multicolumn{4}{|c|}{ Narzędzia } \\
\hline & & wojskowe & gospodarcze & $\begin{array}{l}\text { ideologiczno- } \\
\text {-kulturowe }\end{array}$ & dyplomatyczne \\
\hline 1 & 2 & 3 & 4 & 5 & 6 \\
\hline \multirow{3}{*}{ UE } & Waga relacji & Mało istotna & Kluczowa & Mało istotna & Znacząca \\
\hline & Presja & $\begin{array}{l}\text { Słabo wykorzy- } \\
\text { stywane }\end{array}$ & $\begin{array}{l}\text { Szeroko stoso- } \\
\text { wane }\end{array}$ & $\begin{array}{l}\text { Słabo wykorzy- } \\
\text { stywane }\end{array}$ & Stosowane \\
\hline & Perswazja & $\begin{array}{l}\text { Słabo wykorzy- } \\
\text { stywane }\end{array}$ & $\begin{array}{l}\text { Szeroko stoso- } \\
\text { wane }\end{array}$ & Stosowane & $\begin{array}{l}\text { Słabo wykorzy- } \\
\text { stywane }\end{array}$ \\
\hline \multirow{3}{*}{ USA } & Waga relacji & Kluczowa & Kluczowa & Kluczowa & Kluczowa \\
\hline & Presja & $\begin{array}{l}\text { Słabo wykorzy- } \\
\text { stywane }\end{array}$ & Stosowane & $\begin{array}{l}\text { Słabo wykorzy- } \\
\text { stywane }\end{array}$ & $\begin{array}{l}\text { Słabo wykorzy- } \\
\text { stywane }\end{array}$ \\
\hline & Perswazja & Stosowane & $\begin{array}{l}\text { Szeroko stoso- } \\
\text { wane }\end{array}$ & Stosowane & $\begin{array}{l}\text { Szeroko stoso- } \\
\text { wane }\end{array}$ \\
\hline \multirow{3}{*}{ Rosja } & Waga relacji & Znacząca & Znacząca & Znacząca & Kluczowa \\
\hline & Presja & $\begin{array}{l}\text { Słabo wykorzy- } \\
\text { stywane }\end{array}$ & Stosowane & Stosowane & $\begin{array}{l}\text { Słabo wykorzy- } \\
\text { stywane }\end{array}$ \\
\hline & Perswazja & Stosowane & Stosowane & Stosowane & $\begin{array}{l}\text { Szeroko stoso- } \\
\text { wane }\end{array}$ \\
\hline \multirow{3}{*}{ Japonia } & Waga relacji & Znacząca & Kluczowa & Kluczowa & Znacząca \\
\hline & Presja & Stosowane & \begin{tabular}{|l} 
Szeroko stoso- \\
wane
\end{tabular} & \begin{tabular}{|l}
$\begin{array}{l}\text { Szeroko stoso- } \\
\text { wane }\end{array}$ \\
\end{tabular} & $\begin{array}{l}\text { Szeroko stoso- } \\
\text { wane }\end{array}$ \\
\hline & Perswazja & $\begin{array}{l}\text { Słabo wykorzy- } \\
\text { stywane }\end{array}$ & $\begin{array}{l}\text { Szeroko stoso- } \\
\text { wane }\end{array}$ & $\begin{array}{l}\text { Szeroko sto- } \\
\text { sowane (choć } \\
\text { nieskuteczne) }\end{array}$ & Stosowane \\
\hline
\end{tabular}




\begin{tabular}{|c|l|l|l|l|l|}
\hline 1 & \multicolumn{1}{|c|}{2} & \multicolumn{1}{|c|}{3} & \multicolumn{1}{c|}{5} & \multicolumn{1}{c|}{6} \\
\hline \multirow{5}{*}{ Afryka } & Waga relacji & Mało istotna & Znacząca & Znacząca & Mało istotna \\
\cline { 2 - 6 } & Presja & $\begin{array}{l}\text { Słabo wykorzy- } \\
\text { stywane }\end{array}$ & $\begin{array}{l}\text { Słabo wykorzy- } \\
\text { stywane }\end{array}$ & $\begin{array}{l}\text { Słabo wykorzy- } \\
\text { stywane }\end{array}$ & $\begin{array}{l}\text { Słabo wykorzy- } \\
\text { stywane }\end{array}$ \\
\cline { 2 - 6 } & Perswazja & $\begin{array}{l}\text { Słabo wykorzy- } \\
\text { stywane }\end{array}$ & $\begin{array}{l}\text { Szeroko stoso- } \\
\text { wane }\end{array}$ & $\begin{array}{l}\text { Szeroko stoso- } \\
\text { wane }\end{array}$ & Stosowane \\
\hline \multirow{4}{*}{ ASEAN } & Presja & Stosowane & $\begin{array}{l}\text { Szeroko stoso- } \\
\text { wane (uzależnio- } \\
\text { ne od kraju) }\end{array}$ & $\begin{array}{l}\text { Szeroko stoso- } \\
\text { wane (uzależnio- } \\
\text { ne od kraju) }\end{array}$ & Stosowane \\
\cline { 2 - 6 } & Perswazja & Stosowane & $\begin{array}{l}\text { Szeroko stoso- } \\
\text { wane }\end{array}$ & $\begin{array}{l}\text { Szeroko stoso- } \\
\text { wane }\end{array}$ & Stosowane \\
\cline { 2 - 6 } & Wajwaczaca & Kluczowa & Mało istotna & Znacząca \\
\cline { 2 - 6 } & Presja & $\begin{array}{l}\text { Szeroko stoso- } \\
\text { wane }\end{array}$ & $\begin{array}{l}\text { Słabo wykorzy- } \\
\text { stywane }\end{array}$ & $\begin{array}{l}\text { Słabo wykorzy- } \\
\text { stywane }\end{array}$ & $\begin{array}{l}\text { Szeroko stoso- } \\
\text { wane }\end{array}$ \\
\cline { 2 - 6 } & Perswazja & $\begin{array}{l}\text { Słabo wykorzy- } \\
\text { stywane }\end{array}$ & $\begin{array}{l}\text { Szeroko stoso- } \\
\text { wane }\end{array}$ & Stosowane & $\begin{array}{l}\text { Szeroko stoso- } \\
\text { wane }\end{array}$ \\
\hline
\end{tabular}

Źródło: Opracowanie własne.

\section{Narzędzia dyplomatyczne}

Z punktu widzenia narzędzi politycznych i dyplomatycznych Chinom, wraz ze wzrostem znaczenia gospodarki narodowej, udało się stworzyć platformy dialogu strategicznego z Waszyngtonem. Obok wizyt najważniejszych polityków, kluczowe miejsce od 2009 r. zajmuje Dialog Strategiczny i Gospodarczy oraz od 2006 r. Dialog na Wysokim Szczeblu. Ważne jest to, że podobne fora mają prowadzić do powolnego skłaniania Ameryki w kierunku niwelowania wspierania Tajwanu jako quasi-niezależnego podmiotu oraz rezygnacji z piętnowania Chin za łamanie praw człowieka. Tu jednak skuteczność nacisku dyplomatycznego nie przynosiła spodziewanych rezultatów, stąd też podjęto bezpośrednie rozmowy z władzami Tajwanu. W omawianym okresie politykę Chin wobec Tajwanu cechowała stałość celu nadrzędnego: zjednoczenia państwowego, połączona z elastycznym podejściem do środków jego osiągnięcia. Uwagę zwraca przede wszystkim łączne traktowanie poszczególnych środków, żaden z nich nie był bowiem stosowany w izolacji od pozostałych. Ogólna strategia, zawierająca się w jednoczesnym kierowaniu zachęt oraz wywieraniu presji, była spójna we wszystkich omawianych obszarach. Dużą rolę w gotowości Chin do ustępstw na rzecz Tajwanu odegrało 
pojawienie się wiarygodnego w oczach Pekinu partnera do rozmów - będącego najpierw w opozycji, a od 2008 r. ponownie sprawującego władzę Kuomintangu. Dzięki temu możliwe było rozwinięcie przez ChRL polityki zjednoczonego frontu, polegającej na podjęciu współpracy z ideologicznymi przeciwnikami w imię osiągnięcia zwycięstwa nad wspólnym przeciwnikiem, w tym wypadku zwolennikami formalnej niepodległości Tajwanu.

Politycznie Chiny rozwijały dialog międzypartyjny pomiędzy KPCh i tajwańskimi partiami opozycyjnymi z lat 2000-2008, na czele z Kuomintangiem. Pokazały tym samym elastyczność, połączoną z konsekwentnym realizowaniem założeń polityki zjednoczonego frontu. Należy zwrócić także uwagę na daleko idącą instytucjonalizację powyższych działań, połączoną z kierowaniem zaleceń do władz tajwańskich. Co więcej, od 2008 r. Chiny nie tylko ponownie przystąpiły do funkcjonującego przed 1999 r. nieoficjalnego dialogu międzyrządowego, ale kontynuowały wcześniejsze kontakty międzypartyjne, w efekcie znacznie poszerzając zakres wzajemnych relacji. Charakterystyczny był tu okres prezydentury Chen Shui-biana (2000-2008), kiedy to Pekin aktywnie przeciwstawiał się wszelkim tajwańskim próbom zwiększania obecności międzynarodowej. W większym stopniu, niż miało to miejsce wcześniej, wykorzystywano w tym celu nacisk ze strony innych państw, głównie Stanów Zjednoczonych.

Dla realizacji ważniejszych celów politycznych, na czele z podpisaniem układu gospodarczego (ECFA), Chiny były jednak gotowe na ustępstwa. Stąd po 2008 r. nie doprowadziły do zerwania przez niektóre państwa trzecie relacji dyplomatycznych z Tajwanem oraz zgodziły się na jego udział w pracach Światowej Organizacji Zdrowia. Jednocześnie wyraźnie dały do zrozumienia, że dalsze postępy w tym zakresie będą możliwe tylko w przypadku postępów w dialogu politycznym ponad Cieśniną.

Oprócz prób nacisków na Stany Zjednoczone w rozmowach dwustronnych i uzyskania korzystnego stanowiska w kwestii Tajwanu, Chiny próbowały, poprzez rozmowy sześciostronne, stworzyć wielostronną platformę bezpieczeństwa z udziałem USA. Podobnie myślano w Waszyngtonie, jednak inaczej widziano tu proces tworzenia takich struktur. Pekin nie zrezygnował bowiem z utrzymywania „Swojego wasala” w Pjongjangu, choć Korea Północna prowadziła do zantagonizowania Stanów Zjednoczonych i Chin. W tej sytuacji rozmowy sześciostronne poniosły fiasko, a dyplomacja amerykańska rozpoczęła rozmowy dwustronne z przedstawicielami Korei Północnej.

Z perspektywy aktywności dyplomacji chińskiej istotny jest region Azji Południowo-Wschodniej, potrzebny Chinom do zagwarantowania stabilnego i długotrwałego wzrostu gospodarczego w przyjaznym środowisku międzynarodowym. Wykorzystują one przy tym całą gamę środków dyplomatycznych, aby wyeliminować negatywne emocje i obawy o zagrożenie $\mathrm{z}$ ich strony, poczynając od silniejszego wspierania regionalnego multilateralizmu, w tym: ASEAN+3, EAS, 
ARF, APEC, CAFTA, po umacnianie interakcji z przywódcami państw regionu. Wielość form bezpośredniej współpracy międzypaństwowej i międzyresortowej sprawia, że obecnie łączące oba podmioty więzy wydają się nierozerwalne, zwłaszcza współpraca gospodarcza w ramach CAFTA. Chiny już przegoniły znaczących graczy w regionie i pełnią rolę inicjatora wielu przedsięwzięć.

Pozytywny obraz działań politycznych w regionie musi być jednak zweryfikowany pewnymi negatywnymi środkami, które Pekin również umiejętnie stosuje. Coraz wyraźniejszy staje się obraz ASEAN podzielonego na tych, którzy lepiej współpracują z Chinami, oraz tych, którzy szukają wsparcia dla realizacji swoich aspiracji wśród innych graczy, przede wszystkim USA i Japonii. Nie wszyscy eksperci są skłonni uwierzyć w zapewnienia chińskich przywódców. Chiny potrafią rozgrywać różnice występujące między państwami ASEAN i zdarza się, że Stowarzyszenie nie jest w stanie wypracować wspólnej pozycji, zwłaszcza w tak newralgicznym temacie, jakim są Paracele i Spratly. ASEAN nie poparło prób Filipin i Wietnamu umiędzynarodowienia konfliktu, a raczej pozycję Chin, które były temu przeciwne. Wykorzystywanie relacji wewnątrz ASEAN jest jedną z metod politycznych Chin.

Konkurentem Chin w regionie Azji Południowo-Wschodniej jest Japonia. Pekin przywiązywał duże znaczenie do utrzymania bliskich relacji z zaprzyjaźnionymi politykami japońskimi z największych partii. Eskalacja kryzysów dyplomatycznych doprowadziła jednak do znacznego osłabienia frakcji propekińskiej na japońskiej scenie politycznej, co z kolei negatywnie wpłynęło na możliwości oddziaływania ChRL na rząd w Tokio. Jednym z narzędzi wywierania przez Chiny presji na Japonię było zawieszanie wzajemnych wizyt urzędników wysokiego szczebla, a nawet całkowita odmowa spotkań na szczycie, zwłaszcza pod koniec rządów Koizumiego Jun'ichirō (2005-2006).

Oprócz regionu Azji Południowo-Wschodniej, z całą pewnością pozytywne zmiany w stosunkach bilateralnych dotyczą Rosji. Obecnie podstawową zasadą jest odideologizowanie stosunków wzajemnych i oparcie ich o ideę ,partnerstwa strategicznego w XXI w.” Idea ,partnerstwa strategicznego” została wypracowana na szczycie obu państw w kwietniu 1996 r., w czasie wizyty prezydenta Jelcyna w Chinach, i wpisana do deklaracji końcowej. Zaznaczono, że celem współpracy jest utrzymanie regionalnej stabilności, podkreślono również, że nie jest ona skierowana przeciw żadnemu innemu państwu. Prezydent Jiang Zemin nazwał te relacje mianem , ani sojuszu, ani konfrontacji”, ale równouprawnienia i wzajemnych korzyści. W latach 2000. prezydenci kontynuowali spotkania, które odbywały się nawet kilka razy w roku, np. w roku 2010 prezydent Hu Jintao i Dmitrij Miedwiediew spotkali się sześć razy. Służą temu inicjatywy wielostronne, w tym Szanghajska Organizacja Współpracy, BRICS, spotkania w ramach G20, APEC, EAS i inne. W relacjach wzajemnych ważny był rok 2001, kiedy podpisano Układ o dobrym sąsiedztwie i współpracy wzajemnej. 
Na pewno współpraca polityczna będzie ważniejszą sferą wzajemnych relacji rosyjsko-chińskich. Będę istniały punkty sporne, ale strony będą szukać wspólnych interesów i stabilizacji. Chiny potrzebują przyjaznego zaplecza, bo nadal istnieje sporo nierozwiązanych konfliktów: w kwestii sporu o wyspy Diaoyu/Senkaku z Japonią uzyskały one poparcie Rosji, która pozostaje neutralna również w sporze o wyspy na Morzu Południowochińskim, mimo że uczestnikiem tego sporu jest jej ważny partner w regionie - Wietnam. Chiny liczą na wsparcie w razie rozruchów w Tybecie czy muzułmańskim Xinjiangu. Chińczycy potrzebują wsparcia Rosji w walce z ekstremizmem muzułmańskim w Azji Srodkowej. Wolą dzielić się wpływami w tej ważnej strategicznie części Azji (położenie oraz surowce) z Rosjanami niż Amerykanami, którzy starają się włączyć Kazachstan czy Turkmenistan w orbitę własnych wpływów. Wspólne zainteresowanie stabilnością $\mathrm{w}$ regionie to również współpraca $\mathrm{w}$ ramach rozmów sześciostronnych w sprawie Korei i minimalizowanie groźby destabilizowania sytuacji wynikającej z czynnika koreańskiego. Z punktu widzenia Pekinu partnerstwo z Rosją może się też okazać mocną kartą w grze o Tajwan, jaką Pekin prowadzi z Ameryką. Tymczasem problem granic z Rosją został zamknięty i można zaryzykować stwierdzenie, że mimo istniejących w tle wzajemnych relacji nieufności dla Chin Rosja pozostaje ich partnerem strategicznym. Państwa razem krytykowały Zachód za poparcie kolorowych rewolucji w Gruzji, Kirgistanie i Ukrainie w latach 2003-2005.

W polityce chińskiej i rosyjskiej element równowagi sił, kierunek budowy świata wielobiegunowego, podkreślanie wspólnych wartości w polityce międzynarodowej, suwerenność państw, nieingerowanie w sprawy wewnętrzne są podstawowymi zasadami tworzenia relacji międzynarodowych - Chiny nie chcą monopolu żadnej ze stron trzecich. Współpraca z Rosją może się im przydać dla utrzymania równowagi sił w Azji Północnej i zabezpieczenia przed jednostronnym umocnieniem wpływów USA i Japonii.

Chiny nie do końca umiejętnie używały narzędzi dyplomatycznych w swoich relacjach z UE, wydaje się, że niezbyt dobrze rozumieją skomplikowane mechanizmy rządzące kształtowaniem polityki zagranicznej tej struktury. Najlepszym przykładem jest tu ofensywa dyplomatyczna Pekinu z lat 2003-2004, która miała na celu zniesienie embarga na sprzedaż broni - do rozmów dyplomatycznych włączono przedstawicieli Komisji Europejskiej, posiadającej bardzo ograniczone kompetencje w tej sprawie.

W omawianym okresie doszło do niezwykle daleko idącej instytucjonalizacji dialogu Chiny-UE. Powstało kilkadziesiąt forów współpracy i dialogu, relacje zostały nazwane „strategicznym partnerstwem”. Pekin tym samym próbował się dostosować do specyficznych oczekiwań bardzo zbiurokratyzowanych struktur unijnych, a jednocześnie tworzyć wygodne dla siebie miraże ,podjęcia współpracy" - zgodnie z oczekiwaniami strony unijnej. Najlepiej widać to na przykładzie dialogu dotyczącego praw człowieka oraz ochrony środowiska.

Chiny spróbowały też zastosować mechanizm mocnego nacisku na Brukselę poprzez przełożenie szczytu z 2008 r., w reakcji na protybetańskie gesty polityczne 
niektórych państw członkowskich. W Europie odebrano to jako „tupnięcie nogą”, które wywołało krótkotrwały kryzys dyplomatyczny - nie przyniósł on jednak Pekinowi żadnych konkretnych korzyści i ta forma nacisku nie była już powtarzana.

Często stosowanym narzędziem były próby rozgrywania poszczególnych krajów unijnych przeciwko sobie. Doraźnie przynoszą one oczekiwany skutek - stronie unijnej ciężko jest zachować jednolite stanowisko w kontaktach z Pekinem, gdyż pokusa ugrania czegoś dla siebie (np. dużego kontraktu gospodarczego) jest niezwykle kusząca. Polityka poszczególnych krajów unijnych wobec Chin zmieniała się jednak wraz ze zmianą władzy (np. prochiński rząd Gerharda Schrödera w Niemczech oraz zdecydowanie bardziej krytyczny Angeli Merkel), więc „system kar i nagród” ma ograniczone długofalowe oddziaływanie.

Z uwagi na zasoby naturalne obszarem zainteresowania polityki chińskiej jest kontynent afrykański. Rozproszenie ośrodków decyzyjnych po stronie chińskiej oraz podział Afryki na kilkadziesiąt suwerennych państw spowodował, że strona chińska podjęła inicjatywę sformalizowania stosunków chińsko-afrykańskich w postaci międzynarodowego forum. Forum Współpracy Chińsko-Afrykańskiej (FOCAC), działające od 2000 r., w skład którego wchodzi 49 państw, jest zyskującą na znaczeniu formą multilateralnego dialogu między Pekinem i państwami kontynentu oraz narzędziem konsolidacji wysiłków poszczególnych instytucji chińskich. Regularne szczyty ministerialne FOCAC pozwalają najwyższym władzom ChRL i KPCh publicznie formułować założenia polityki wobec Afryki, do stosowania których zobowiązane są rywalizujące instytucje, jak MSZ czy Ministerstwo Handlu. Chęć wypracowania bardziej spójnej odpowiedzi strony afrykańskiej prowadzi również do chętnej współpracy Pekinu z takimi organizacjami, jak Unia Afrykańska i NEPAD.

W 2012 r. miało miejsce 10 wizyt delegacji chińskich i 13 wizyt delegacji afrykańskich do Chin. Motywacja działań chińskich z punktu widzenia interesów globalnych jest bardziej jasna - chodzi o spojrzenie na Afrykę nie tylko jako na zaplecze surowcowe, ale o budowę strefy wpływów i wyparcie z niej państw z zachodniej strony: USA, Wielkiej Brytanii czy Francji, o czym świadczą ostatnie działania Francji w Mali. Chiński MSZ skrytykował malijskich powstańców, ale nie chciał mieszać się w konflikt. Chiny być może przekonały swoich kontrahentów, że w odróżnieniu od USA i UE współpraca z nimi przyniesie im wyłącznie korzyści.

\section{Narzędzia ideologiczno-kulturowe}

Narzędzia soft power, szeroko dyskutowane w literaturze chińskiej i zachodniej, mogą okazać się przydatne nie tyle do promowania chińskiej kultury, ile jako narzędzia o charakterze defensywnym do ochrony chińskiego systemu politycznego przed wpływami Zachodu, w tym przede wszystkim przed amerykańskim promowaniem demokracji liberalnej w Chinach. W tym kontekście należy postrzegać 
wykorzystanie takich narzędzi w odniesieniu do Waszyngtonu. Potwierdzeniem takiego podejścia mogą być przytaczane badania opinii amerykańskiej, która w dalszym ciągu postrzega Chiny jako głównego rywala. Z drugiej jednak strony, na co wskazują lekcje „rewolucji kulturalnej”, zbyt duże eksponowanie „modelu chińskiego" może stać się przyczyną krytyki Chin i uznania Państwa Środka za otwartego rywala ideologicznego.

Sfera kultury, ze względu na bliskość kulturową, również stanowi szczególny obszar relacji ponad Cieśniną Tajwańską. Choć Chiny chciałyby uregulowania także tego obszaru relacji z Tajwanem, w praktyce jest to bardzo trudne, głównie ze względu na liczne kontrowersje wynikające $\mathrm{z}$ różnicy doświadczeń oraz systemów politycznych po obu stronach. Co więcej, podstawowym problemem w tej dziedzinie jest tworzenie się odrębnej tożsamości tajwańskiej, która paradoksalnie zaczęła być istotnym elementem w momencie umożliwienia większej otwartości na Chiny kontynentalne.

Dyplomacja publiczna odgrywa pewną rolę $\mathrm{w}$ umacnianiu pozytywnego wizerunku Chin w niektórych państwach rozwijających się. Najbardziej konstruktywną metodą, przynoszącą najlepsze efekty w kontaktach z ASEAN, jest pokazanie atrakcyjności modelu rozwojowego Chin, który w odróżnieniu od państw Zachodu nie jest kombinacją wolnego rynku i demokracji liberalnej, ale półrynkowego systemu gospodarczego i nieliberalnego systemu politycznego, opartego na rządach partii komunistycznej. Ten „konsensus pekiński”, w odróżnieniu od „waszyngtońskiego”, może być bardziej atrakcyjny dla wielu państw regionu. Chińskie soft power w Azji Południowo-Wschodniej może uwzględniać chińską kulturę, zasady współpracy i uczestnictwa w multilateralizmie ASEAN.

Chiny zaczęły wykorzystywać szeroką gamę środków związanych z dyplomacją kulturalną. W państwach ASEAN pojawiły się programy nauki języka chińskiego, a także wolontariusze chińscy uczący języka. Chińska kultura, kuchnia, kaligrafia, kino, sztuka, akupunktura, medycyna tradycyjna, moda weszły do kultury regionu. Najbardziej rozpowszechnioną formą nauki języka chińskiego są obecnie Instytuty Konfucjusza. W państwach ASEAN istnieje 41 Instytutów, ale są rozmieszczone nierównomiernie: najwięcej jest w Tajlandii (23), w Indonezji siedem, na Filipinach trzy, w Malezji, Singapurze i Myanmarze po dwa, w Laosie i Kambodży po jednym.

Pomimo bliskości kulturowej dyplomacja publiczna Chin wobec Japonii, choć szeroko stosowana, okazała się nieskuteczna. Było to spowodowane silnymi konfliktami interesów między oboma krajami (problemy historyczne, spór terytorialny o wyspy Diaoyu/Senkaku), które doprowadziły do znacznej eskalacji kryzysów dyplomatycznych, zwłaszcza w latach 2005, 2010 i 2012. Tworzenie pozytywnego wizerunku Chin w Japonii było niemożliwe ze względu na świadomość japońskiego społeczeństwa, jak bardzo uczucia antyjapońskie są rozpowszechnione w ChRL. 
Posługiwanie się „kartą historyczną” stanowiło najbardziej charakterystyczne narzędzie Chin w polityce wobec Japonii. Pekin w mniej lub bardziej zawoalowany sposób wykorzystywał antyjapoński nacjonalizm w celu wywierania presji na rząd w Tokio. „Karta historyczna” - charakterystyczna dla relacji z Japonią i częściowo z USA - w przypadku stosunków z Japonią wpływała, często w niekontrolowany sposób, na wszystkie rodzaje narzędzi, którymi Chiny posługiwały się $\mathrm{w}$ relacjach z tym krajem.

Także w relacjach z Rosją Chiny sięgają po narzędzia soft power. Wydaje się jednak, że te metody polityki zagranicznej są jedynie uzupełnieniem innych. Można więc wymienić organizowane wzajemnie Dni Kultury Rosyjskiej i Dni Kultury Chińskiej (2003-2004), Rok Chin w Rosji i Rok Rosji w Chinach (20062007) czy Rok Języka Rosyjskiego w Chinach i Rok Języka Chińskiego w Rosji (2009-2010), otwieranie Instytutów Konfucjusza (obecnie jest ich 22, najwięcej na Syberii i Rosyjskim Dalekim Wschodzie). Problem związany z budowaniem wzajemnych relacji, który najczęściej jest powtarzany w publikacjach naukowych i różnego typu analizach, to brak zaufania, wynikający z doświadczeń historycznych. Chińczycy uważają, że Rosja i Rosjanie myślą europejskimi kategoriami i nie chcą się konfliktować z Europą i Zachodem. Z kolei Rosjanie mówią o chińskim zagrożeniu na Syberii. Mowa jest też o tym, że silne Chiny mogą zmarginalizować Rosję. Na tej nucie grają natomiast Amerykanie, zachęcając Moskwę do odgrywania bardziej aktywnej roli w Azji Wschodniej.

W relacjach Chin z UE zarówno narzędzia wojskowe, jak i kulturalne miały marginalne znaczenie. Widać wyraźny prymat sfery gospodarczej w relacjach dwustronnych. Pekin starał się oddziaływać na Unię w sposób bardzo kompleksowy i z uwzględnieniem specyfiki partnera. Narzędzia o długofalowym oddziaływaniu (np. promocja kultury chińskiej poprzez Instytuty Konfucjusza) były łączone z działaniami doraźnymi, wykorzystującymi dogodny moment.

ChRL w swojej polityce wobec Afryki posługuje się narzędziami retorycznymi, odwołującymi się do wspólnoty Chin i kontynentu jako członków ubogiego globalnego Południa. Retoryka solidarności i wzajemnego wsparcia oraz poszanowania suwerenności i nieingerencji w wewnętrzne sprawy suwerennych państw jest wykorzystywana przez wszystkie chińskie ośrodki zaangażowane w politykę afrykańską.

\section{Narzędzia gospodarcze}

Dynamiczny rozwój ekonomiczny Chin pozwala efektywnie zastosować gospodarcze środki realizacji polityki zagranicznej i osiągania zamierzonych celów. W stosunku do głównego punktu odniesienia chińskiej polityki zagranicznej - Stanów Zjednoczonych próbowano wykorzystać inwestycje bezpośrednie i udział Chin w amerykańskim rynku papierów dłużnych jako narzędzie wpły- 
wania na amerykańskich decydentów. Chiny przyjęły strategię „wykupywania” Ameryki, by w ten sposób prowadzić do zmian zasad gry rządzących mechanizmami gospodarki światowej i zyskiwać dogodną pozycję w celu powolnego umiędzynarodowienia chińskiego yuana. Jednak również takie podejście natrafiło na poważne wyzwania. Amerykanie, traktując Chiny jako potencjalne zagrożenie dla własnego bezpieczeństwa, ograniczały możliwości inwestycji w rodzimy sektor paliwowy czy przejmowanie podmiotów związanych z rynkami kapitałowymi. $\mathrm{Z}$ punktu widzenia równoważenia amerykańskich wpływów uznano, że najlepszą formą będzie aktywna postawa $\mathrm{w}$ tworzeniu nowej architektury gospodarczej świata $\mathrm{w}$ postaci G20.

Ważne, również z punktu widzenia oddziaływania na Stany Zjednoczone, było wykorzystanie narzędzi gospodarczych wobec Tajwanu. Pekin w istocie oddzielił to zagadnienie od ogólnego stanu relacji ponad Cieśniną Tajwańską. Co ważne, Chiny nie tylko tolerowały stale rosnący deficyt handlowy z Tajwanem, ale aktywnie przyczyniały się do jego zwiększania, m.in. poprzez większe otwarcie własnego rynku dla produktów tajwańskich w ramach ECFA oraz wysyłanie misji zakupowych. $Z$ otwarciem na handel powiązane było również wspieranie inwestycji tajwańskich w Chinach kontynentalnych. Powyższy stan wiązał się z coraz wyraźniejszym od 2005 r. bezpośrednim wykorzystywaniem środków gospodarczych do realizacji bieżących celów politycznych. W tym wypadku chodziło głównie o powiększenie grona Tajwańczyków czerpiących korzyści ze współpracy z Chinami, co w założeniach Pekinu miało przełożyć się przynajmniej na spadek poparcia dla idei niepodległości Tajwanu.

Przegląd metod gospodarczych realizacji celów polityki chińskiej wobec regionu Azji Południowo-Wschodniej należy bez wątpienia rozpocząć od roku 1997. Wówczas azjatycki kryzys finansowy pokazał, że Chiny mogą i chcą odgrywać konstruktywną rolę w regionie. Kryzys zmusił państwa do większej troski o własną stabilizację, bez względu na potencjalne zagrożenia ze strony odbudowujących swoją potęgę Chin. Formą instytucjonalizacji współpracy liderów regionu z ASEAN jest ASEAN+1 oraz ASEAN+3 (APT). Za pośrednictwem tych multilateralnych form wypracowano wiele nowych inicjatyw, np. Chiang Mai Initiative, dla wzmocnienia regionalnej stabilności finansowej, powołano z Chinami Boao Forum dla Azji, które działa od 2001 r. Jest to najbardziej prestiżowa organizacja non profit, powołana w celu promowania regionalnej integracji gospodarczej i realizacji celów rozwojowych. W 2009 r., z inicjatywy premiera Wen Jiabao, powstał China-ASEAN Investment Cooperation Fund (CAF), który skupia się na inwestycjach w infrastrukturę, energetykę oraz zasoby naturalne. W dniu 1 stycznia 2010 r. miało miejsce otwarcie strefy wolnego handlu CAFTA.

Pomimo istniejących wątpliwości, bez wątpienia początek XXI w. to większe zbliżenie tych dwóch podmiotów międzynarodowych. Rozpoczął się bum kredytowy, Chiny z biorcy pomocy rozwojowej stały się dawcą, udzielały pożyczek państwom ASEAN. Konkurencja Chin z Japonią o wpływy geopolityczne wy- 
musiła na obu państwach własną politykę inwestycyjną. Wśród wielu określeń analitycy używają pojęcia charm offensive, która ma świadczyć o nowych metodach realizacji celów chińskiej polityki zagranicznej. W słowniku przywódców chińskich na stałe zagościły słowa: wzajemnie korzystna współpraca, win-win cooperation. Dla Chin najważniejszym celem tego przedsięwzięcia była pełna integracja gospodarki chińskiej z globalną w charakterze centrum światowego przemysłu. Chińczykom chodziło o pełniejsze otwarcie rynków azjatyckich, które do tej pory absorbowały jedynie $8 \%$ chińskiego eksportu.

Strategia ASEAN+Chiny polega nie tylko na inwestycjach kapitałowych, ale jest związana $\mathrm{z}$ ich obsługą. Pekin umiejętnie wykorzystuje zainteresowanie Tajlandii, Kambodży, Laosu, Wietnamu i Malezji budową agroinfrastruktury. Pamiętać należy, że Chiny i państwa ASEAN są nadal konkurentami, jeśli chodzi o przyciąganie kapitału w podobnych dziedzinach przemysłu.

Dzięki wysokiemu poziomowi japońskich inwestycji w Chinach i wymiany handlowej między oboma krajami ChRL dysponuje również ważnym narzędziem wywierania presji na rząd w Tokio. Pekin często usiłował wpływać na politykę Japonii pośrednio, w zawoalowany sposób - poprzez japońskich przedsiębiorców zainteresowanych stabilną sytuacją w relacjach bilateralnych.

Dawniej Chiny starały się odseparować współpracę gospodarczą od napięć politycznych, jednak ostatnio zaczęły coraz częściej jawnie wykorzystywać uzależnienie Japonii od handlu z nimi do wywierania presji dyplomatycznej. Najlepszym przykładem tego jest wstrzymanie eksportu do Japonii metali ziem rzadkich w celu skłonienia rządu w Tokio do uwolnienia kapitana chińskiego kutra w $2010 \mathrm{r}$.

Jeśli chodzi o relacje gospodarcze z Rosją, widoczna jest tutaj nierównowaga. Rosja dopiero nabiera dynamizmu rozwojowego, a gospodarka Chin jest już rozpędzona. Chiny stają się dla Rosji pierwszym partnerem, a Rosja dla Chin jest partnerem drugorzędnym. Ten brak balansu Moskwa stara się zmienić, jest partnerem trudnym i stawiającym warunki, ale przewaga znajduje się po stronie Chin. Zwłaszcza na początku lat 2000. polityka wewnętrzna i zagraniczna Chin była podporządkowana bezpieczeństwu energetycznemu. Chiny wchodzą na tereny, które tradycyjnie pozostawały w kręgu zainteresowania Rosji; np. zawarły z Kazachstanem umowę na budowę rurociągów dostarczających ropę i gaz z terenu Morza Kaspijskiego. W 2007 r. nitka rurociągu połączyła pola naftowe w Kazachstanie, będące własnością China National Petroleum Corporation, z chińską prowincją Xinjiang. W grudniu 2009 r. uruchomiono gazociąg z Turkmenistanu przez Uzbekistan i Kazachstan do Chin. Zgodnie z tym porozumieniem Chiny będą otrzymywać $30 \mathrm{mld} \mathrm{m}^{3}$ gazu rocznie przez 30 lat. Porozumienie to ma wpływ na dwustronne relacje rosyjsko-chińskie i jest formą nacisku na Chiny, aby zmiękczyć pozycję negocjacyjną Rosji, która do tej pory miała monopol na eksport gazu w Azji Centralnej i jedynie jedna nitka łączyła Turkmenistan z Iranem niezależnie od niej. Eksport gazu z tego rejonu był całkowicie zależny od infrastruktury rosyjskiej. 
Rosja obawia się też wzrostu chińskich wpływów w Azji Centralnej - tradycyjnym regionie wpływów rosyjskich. Wielu ekspertów widzi możliwą rywalizację chińsko-rosyjską w Azji Centralnej, co jest widoczne w chińskich poszukiwaniach alternatywnych źródeł surowców energetycznych. $Z$ kolei intelektualiści chińscy utrzymują, że nie chodzi o dominację, ale o zrównoważenie wpływów.

W przypadku analizy stosowania narzędzi gospodarczych wobec Unii Europejskiej na uwagę zasługuje wysoki poziom wymiany handlowej pomiędzy UE i Chinami oraz duże zainteresowanie europejskich firm dostępem do rynku chińskiego, w tym zamówień publicznych. Pekin może skutecznie stosować presję na poszczególne kraje członkowskie. Często zawarcie dużych kontraktów uzależniane jest od koncesji politycznych lub gospodarczych (np. przekazanie dostępu do technologii).

Chiny są wciąż mało znaczącym inwestorem z punktu widzenia UE, niemniej jednak ich znaczenie rośnie. W szczególności stało się to widoczne po wybuchu kryzysu zadłużeniowego w strefie euro, kiedy to Pekin mógł odegrać istotną rolę stabilizującą na europejskim rynku obligacji. Prowadzona przez ChRL „dyplomacja obligacji”, w postaci ponawianych zapowiedzi (rzadziej realnych transakcji) zakupu papierów dłużnych pogrążonych w kryzysie krajów europejskich, była jednak głównie elementem budowy wizerunku Chin oraz próbą wymuszenia koncesji politycznych - np. zaprzestania presji na dewaluację juana.

W omawianym okresie doszło do istotnego wzmocnienia pozycji Chin w ich relacjach z UE. Widać to dobrze na przykładzie pomocy gospodarczej - Chinom przestało na niej zależeć. Co więcej, to Pekin stał się pożądanym przez kraje unijne inwestorem w czasach zapaści gospodarczej UE. Wzmocniło to w sposób znaczący pozycję przetargową ChRL względem Unii.

Mimo rosnących obaw Europejczyków inwestorom chińskim przyświecają głównie motywy komercyjne. Analiza zachowania chińskich firm po wejściu na rynek europejski wskazuje na biznesowe, a nie polityczne powody dokonywania inwestycji. Mniejsze upolitycznienie inwestycji w Europie jest spowodowane tym, że aż $2 / 3$ inwestorów chińskich to firmy prywatne - inaczej jest chociażby w przypadku inwestycji chińskich w Afryce.

W odniesieniu do państw Afryki Chiny przede wszystkim korzystają z narzędzi gospodarczych i występują w charakterze mocarnego darczyńcy. Pomoc rozwojowa Chin w Afryce to ok. 45-50 mld USD, a handel rocznie - ok. 200 mld USD (z 47 spośród 53 państw afrykańskich). Te państwa, które zaryzykowały uznanie Tajwanu, automatycznie zostały pozbawione chińskiej pomocy. Chińczycy wykorzystują swoją tradycyjną retorykę, jeszcze z okresu rządów Mao, tzn. występują jako państwo rozwijające się, jako ci, którzy chcą przeciwstawić się zachodniemu imperializmowi i również stać się liderem walki ze światem zachodnim o sprawiedliwość. Na kontynencie w 2012 r. działało ponad 2000 chiń- 
skich kompanii i firm, za pośrednictwem których do Afryki trafiło 10 mld USD inwestycji. Chiny promują też integrację w regionie.

Najważniejszym impulsem dla działań strony chińskiej na kontynencie afrykańskim jest chęć zysku. W tej sytuacji wśród chińskich instytucji rządowych na plan pierwszy wysunęło się Ministerstwo Handlu, co ograniczyło tradycyjne wpływy Ministerstwa Spraw Zagranicznych na formułowanie polityki wobec kontynentu. Choć chęć zapewnienia sobie dostępu do strategicznie ważnych surowców, takich jak ropa naftowa, gaz i metale szlachetne, jest istotnym czynnikiem w chińskiej polityce wobec Afryki, nie jest ona motywowana wyłącznie tymi przesłankami.

\section{Narzędzia wojskowe}

Z punktu widzenia możliwości użycia narzędzi wojskowych podstawowym zagadnieniem była kontynuacja modernizacji chińskich sił zbrojnych. Dalszy postęp technologiczny, przygotowanie do „wojny w cyberprzestrzeni” stanowiły doniosły element $\mathrm{w}$ budowania narzędzi mających służyć nakreślonym celom strategicznym. Mimo że wobec najważniejszych partnerów (USA, UE) Chiny były bardzo powściągliwe w stosowaniu narzędzi wojskowych, to jednak w ciągu dekady rządów Hu Jintao możemy mówić o pojawieniu się nowych zagrożeń bezpieczeństwa związanych z Chinami.

Najważniejszy z nich jest bez wątpienia rozwój chińskiego potencjału cybernetycznego. Aktywność chińskich specjalnych jednostek odpowiedzialnych za działania w cyberprzestrzeni stworzyła szerokie możliwości wykradania wrażliwych informacji z sieci teleinformatycznych państw lub przedsiębiorstw. W przyszłości może to wręcz skutkować przeniesieniem pola walki do przestrzeni internetowej, co stworzy nieznane dotąd możliwości równoważenia potencjału wojskowego innych państw, głównie USA. W tym kontekście ataki hakerów - choć oficjalnie negowane - stały się istotnym narzędziem wywierania presji na Waszyngton, Tokio i stolice europejskie.

Działania w cyberprzestrzeni, uznawane przez zachodnich polityków za jednoznacznie wrogie, są w pewnym sensie równoważone przez tworzenie nowych platform budowy środków zaufania, jak np. wznowienie w 2001 r. dialogu wojskowego z USA czy też zwiększenie przejrzystości chińskiej polityki bezpieczeństwa poprzez regularne (co dwa lata) publikowanie „Białych ksiąg”. Oczywiście do pożądanej przez partnerów transparentności jest jeszcze daleko, niemniej Pekin zaczął wyraźniej dostrzegać wagę środków budowy zaufania dla bezpieczeństwa międzynarodowego.

W odniesieniu do Tajwanu polityka była już inna. Strona chińska nie zdecydowała się nawet na wykonanie symbolicznych kroków mogących przyczynić 
się do budowania wzajemnego zaufania. Chiny niezmiennie stosowały nacisk wojskowy, zarówno poprzez stałe rozbudowywanie potencjału wojskowego, jak i potwierdzanie woli politycznej i gotowości wykorzystania go, ,gdyby zaszła taka konieczność". Co ciekawe, przebiegało to w sposób niezależny od poprawy relacji politycznych ponad Cieśniną Tajwańską, jaka miała miejsce w 2008 r., i postępów we wszystkich innych obszarach stosunków Chin kontynentalnych z Tajwanem.

W swoich relacjach z państwami ASEAN Chiny wykorzystywały środki związane $\mathrm{z}$ budową wzajemnego zaufania $\mathrm{w}$ ramach takich forów, jak ARF czy EAS. W 2003 r. Pekin przystąpił do TAC (Treaty of Amity and Cooperation) oraz podjął rozmowy na temat Protokołu Strefy Wolnej od Broni Atomowej w Azji Południowo-Wschodniej (Protocol to the Treaty on Southeast Asia Nuclear Weapon Free Zone). Podpisanie, na indonezyjskiej wyspie Bali, wspólnej deklaracji na temat strategicznego partnerstwa (Joint Declaration on the Strategic Partnership for Peace and Prosperity) było kolejnym krokiem w kierunku rozwinięcia współpracy politycznej i w dziedzinie bezpieczeństwa. Jednak w omawianym okresie chyba najważniejszym chińskim projektem było zwołanie konferencji ARF na tematy polityczne i bezpieczeństwa (ARF Security Policy Conference ASPC) w 2004 r. do Pekinu

Opisane powyżej działania nie wykluczały mimo to, w przypadku niektórych interesów uznawanych za strategiczne, wykorzystania również negatywnych środków wojskowych, tzn. presji czy użycia siły. W Azji Południowo-Wschodniej najbardziej konfliktogenny charakter ma spór o archipelagi Spratly i Paracele. Co prawda, udaje się łagodzić konflikt metodami dyplomatycznymi (Deklaracja z ASEAN z 2002 r. czy podpisanie porozumienia z Wietnamem w 2011 r.), ale Chiny nie wahały się $\mathrm{w}$ tej konkretnej sprawie używać również innych metod; np. 26 maja 2011 r. trzy chińskie statki zablokowały wietnamski statek należący do państwowej kompanii naftowej Binh Minh. W czerwcu tego samego roku agencje informacyjne doniosły o strzałach ostrzegawczych skierowanych wobec wietnamskich łodzi rybackich, które znajdowały się pięć mil morskich od wyspy Da Dong w archipelagu Spratly. W lipcu 2012 r. miał miejsce kolejny incydent - Chińczycy podjęli decyzję o utworzeniu na wyspie Phu Lam bazy wojskowej Sansha City i przeprowadzeniu tam wyborów. Członkowie ASEAN nie są zgodni co do dalszych wspólnych działań w tej sytuacji. W listopadzie 2012 r. poparli pozycję Chin, że nie będą dążyć do umiędzynarodowienia konfliktu wokół spornych wysp, co oznacza zwycięstwo opcji prochińskiej.

Podobnie elastyczna, stosująca mieszaninę presji i perswazji, była polityka chińska wobec Japonii. Chiny starały się wywrzeć presję na Tokio poprzez powtarzające się naruszenia japońskich wód przez chińskie okręty, ale jednocześnie prowadzone były wzajemne wizyty okrętów wojennych, mające budować zaufanie pomiędzy krajami. Pod koniec prezydentury Hu Jintao można było zaobserwować znaczny wzrost asertywności ChRL w polityce wobec Japonii. Był on 
szczególnie widoczny na polu wojskowym (coraz częstsze naruszenia japońskich wód przez chińskie okręty wojenne, rozpoczęcie regularnych patrolów w okolicy spornych z Japonią wysp Senkaku/Diaoyu).

W relacjach z Rosją najważniejszą platformą służąca do budowy środków zaufania jest Szanghajska Organizacja Współpracy. Poprzez tę organizację oba państwa starają się realizować swoje interesy w Azji Centralnej. W wymiarze wojskowym godne podkreślenia są wspólne ćwiczenia wojskowe. Oba państwa przywiązują szczególną wagę do zachowania suwerennych praw do postępowania wobec mniejszości (Czeczenia, Ujgurzy i Tybet) i zasady nieingerencji w sprawy wewnętrzne. Pekin popiera jednak Rosję w sporze z Japonią o Kuryle, a Rosja w zamian za to zachowuje neutralną postawę wobec sporu o archipelagi Spratly i Paracele.

W omawianym w książce okresie niewątpliwie znacząco wzrosła pozycja wojskowa Chin. Szybki rozwój gospodarczy umożliwiał stałe zwiększanie wydatków na zbrojenia, co prowadziło do poprawy chińskich zdolności wojskowych. Jeśli dodać do tego rozwój nowoczesnych, cybernetycznych zasobów wojskowych, to bez wątpienia można stwierdzić, że możliwości wykorzystania przez Chiny narzędzi wojskowych znacząco wzrosły. Zaowocowało to wzrostem chińskiej asertywności politycznej w ostatnich latach, ale skala użycia narzędzi wojskowych przez Pekin była w okresie rządów ekipy Hu Jintao relatywnie niewielka w porównaniu do innych instrumentów polityki zagranicznej.

$* \quad * \quad *$

Jak widać w tabeli 9.1, dominującym rodzajem narzędzi, którym Chiny posługują się wobec wszystkich znaczących aktorów stosunków międzynarodowych, są instrumenty ekonomiczne.

Wykorzystując rosnący potencjał gospodarczy, Chińska Republika Ludowa próbuje włączyć się w budowę nowego ładu międzynarodowego. Jednak takie ambicje związane są przede wszystkim z koniecznością podtrzymania pokojowych relacji i unikania szerszego konfliktu ze Stanami Zjednoczonymi. Po przejęciu władzy przez Hu Jintao w 2002 r. dyplomacja chińska starała się ograniczać amerykańską aktywność w regionie Azji Wschodniej. Wychodząc z założeń ograniczania możliwości konfliktu z Waszyngtonem, całość narzędzi stosowanych w chińskiej polityce zagranicznej podporządkowana jest równoważeniu wpływów amerykańskich w regionie, by w ten sposób kreować maksymalnie korzystną sytuację dla dalszej modernizacji Chin. Stąd też podejmowano liczne inicjatywy dyplomatyczne mające integrować Azję Wschodnią i Południowo-Wschodnią z Chinami.

Ważną determinantą projekcji chińskich narzędzi w polityce zagranicznej w wymiarze soft power stał się kryzys ekonomiczny z 2008 r. W wyniku kry- 
zysu ekonomicznego dominacja Waszyngtonu została ograniczona do wymiaru wojskowego i przewagi technologicznej, a kryzys gospodarczy spowodował spadek znaczenia dolara amerykańskiego na międzynarodowych rynkach. Z punktu widzenia Chin i stosowanych narzędzi w polityce wobec Waszyngtonu sytuacja ta przedstawiała się korzystnie. W światowym dyskursie pojawiły się nowe pojęcia, takie jak „chiński model” czy „konsensus pekiński”. W sytuacji kryzysu i załamania gospodarczego Stanów Zjednoczonych to miękkie oddziaływanie stanowiło istotny element $\mathrm{w}$ równoważeniu amerykańskiego potencjału, a tym samym ochrony interesów chińskich. Ponadto Stany Zjednoczone, chcąc wyjść z kryzysu, musiały skoncentrować się na rozwiązywaniu problemów wewnętrznych. W perspektywie krótkoterminowej uzależnienie gospodarcze USA przyniosło spodziewane efekty zmniejszania roli Ameryki w regionie, a przez to unikania i ograniczania możliwych płaszczyzn bilateralnego konfliktu.

Taka sytuacja wydawała się korzystna, a Chiny mogły odgrywać coraz bardziej konstruktywną rolę w regionie Azji Wschodniej, co również zostało odnotowane w tabeli zbiorczej. Wraz z przygotowaniami do zmiany władzy na XVIII Zjeździe i koniecznością stworzenia zaplecza politycznego przez Xi Jinpinga na znaczeniu zyskiwała grupa związana z Chińską Armią Ludowo-Wyzwoleńczą. W naturalny sposób warunkowało to wzrost znaczenia armii w strukturach decyzyjnych Chińskiej Republiki Ludowej. Jak wynika z tabeli 9.1, narzędzia wojskowe miały większe znaczenie w polityce wobec sąsiadów niż wobec bardziej oddalonych państw, co świadczy o nadal ograniczonych możliwościach projekcji siły przez Chiny na skalę światową. Eskalacja konfliktów z państwami Azji Południowo-Wschodniej na Morzu Południowochińskim w pierwszej połowie 2012 r. oraz z Japonią w drugiej połowie 2012 r., jak i brak postępu w rozmowach sześciostronnych dotyczących denuklearyzacji Korei Północnej, skłoniły Waszyngton do uznania regionu Azji i Pacyfiku za „rdzeń” amerykańskiej polityki zagranicznej. Dodatkowym elementem amerykańskiego powrotu do Azji i Pacyfiku była negatywna ocena propozycji G2 przez władze w Pekinie. Z tego punktu widzenia pivot to Asia winien być uznany jako próba wymuszenia na Chinach przyjęcia amerykańskiej propozycji. Jak się zatem okazało, paradoks chińskich inwestycji w amerykańskie papiery dłużne polega na tym, iż rząd chiński po części sponsoruje amerykański ,zwrot do Azji”. Taka sytuacja wymusiła na decydentach chińskich ograniczenia wykorzystywania narzędzi oddziaływania soft power przy zwiększającym się znaczeniu struktur siłowych, mających coraz większy wpływ na proces decyzyjny w polityce zagranicznej. 